\title{
GEOLOGICAL CONSTRUCTION OF SOUTHERN PART OF IONIAN ZONE BASED ON INTERPRETATION OF SEISMIC DATA
}

\author{
V. BARE ${ }^{1}$, P. BAKO ${ }^{1}$, V. NGRESI ${ }^{1}$, V. BARE ${ }^{1}$, L. NGRESI ${ }^{1}$, M. BAKO ${ }^{1}$
}

\begin{abstract}
The Ionian zone is the main object of seismic interpretation for a long time. Within this framework, we shall analyze the new seismic intrpretation methods used in oil and gas exploration in the western part of Ionian zone.

The Ionian zone is very complex involving certain tectonic faults. In the central part, we can see the duplex tectonic style. Anticline belts from east to west can be interpreted.The Ionian zone comprises three anticline belts:Berati belt, Kurveleshi belt and Cika belt.

By application of SeisWork2D in the eastern part of the belt, we have evidenced some perscpective structures, meanwhile in the western part, the seismic quality is very chaotic. Kurveleshi belt is constructed by structures of various forms and dimensions associated with developed tectonics up to thrusting. Cika anticline belt is constructed mainly by prolonged structures of considerable dimensions associated with evaporate outcrops as in Xara, Fterra, Cika etc.
\end{abstract}

KEYWORDS: Ionian zone, tectonic belts, thrust, SeisWork2D, seismic sections, seismic interpretation, tectonic fault, duplex tectonic style

\section{INTRODUCTION}

Due to its geographical position, Albania makes up a geological point so complicated as much as interesting for oil and gas exploration.

The quality of seismic data in thrust areas can be improved with the best integration of seismic and geological data and the use of new technology for seismic interpretation.

From Albania tectonic map (Fig. 1) we can see some thrust tectonic zones, which are structurally complex with attendant seismic imaging problems.

A thrust is a low angle reverse fault, commonly dipping less than $30^{\circ}$. Variations in the mechanical properties of the deforming sequence at the base of a thrust unit exert a profound influence on thrust shape.

In the first period, interpretation was performed on paper sections by hand and the prepared structural maps have given useful contribution in imaging of geological features and the main tectonic characteristics of the areas. The discovery of oil and gas fields such as Cakran, Amonice, Divjake, and Panaja (ref. 1) are related with this period.

Application of the SeisWork2D as a powerful interpretative tool gives us new insight into the subsurface. This new method is able to predict the subtle details that would be otherwise hidden on paper sections and can reveal on screen, thanks to color, high resolutions graphics and a wide variety of display options. Due to the interpretation we have tied outcrop information to seismic sections, acquiring both sets of data simultaneously in the field. However, the scale of structures seen at outcrop may be an order of magnitude smaller than those resolved on seismic sections. We will describe the effect of new seismic interpretation according to the thrust belts of the Ionian Zone.

This paper is presented to show the supremacy of workstation interpretation applications in an effort to evidence subtle details.

\section{THE IONIAN ZONE}

The Ionian zone occupies the southwestern part of Albania with SE-NW axis (Fig. 1) and comprises three anticlines belts:

A. Berati anticline belt, in the eastern margin of the zone

B. Kurveleshi anticline belt, in the central part of the zone and seismic, has made it possible to spatially map the carbonates.

1. Oil \& Gas Institute, Geophysical Department, Geophysicist, Fier, Albania 


\section{A. The Berati anticline Belt}

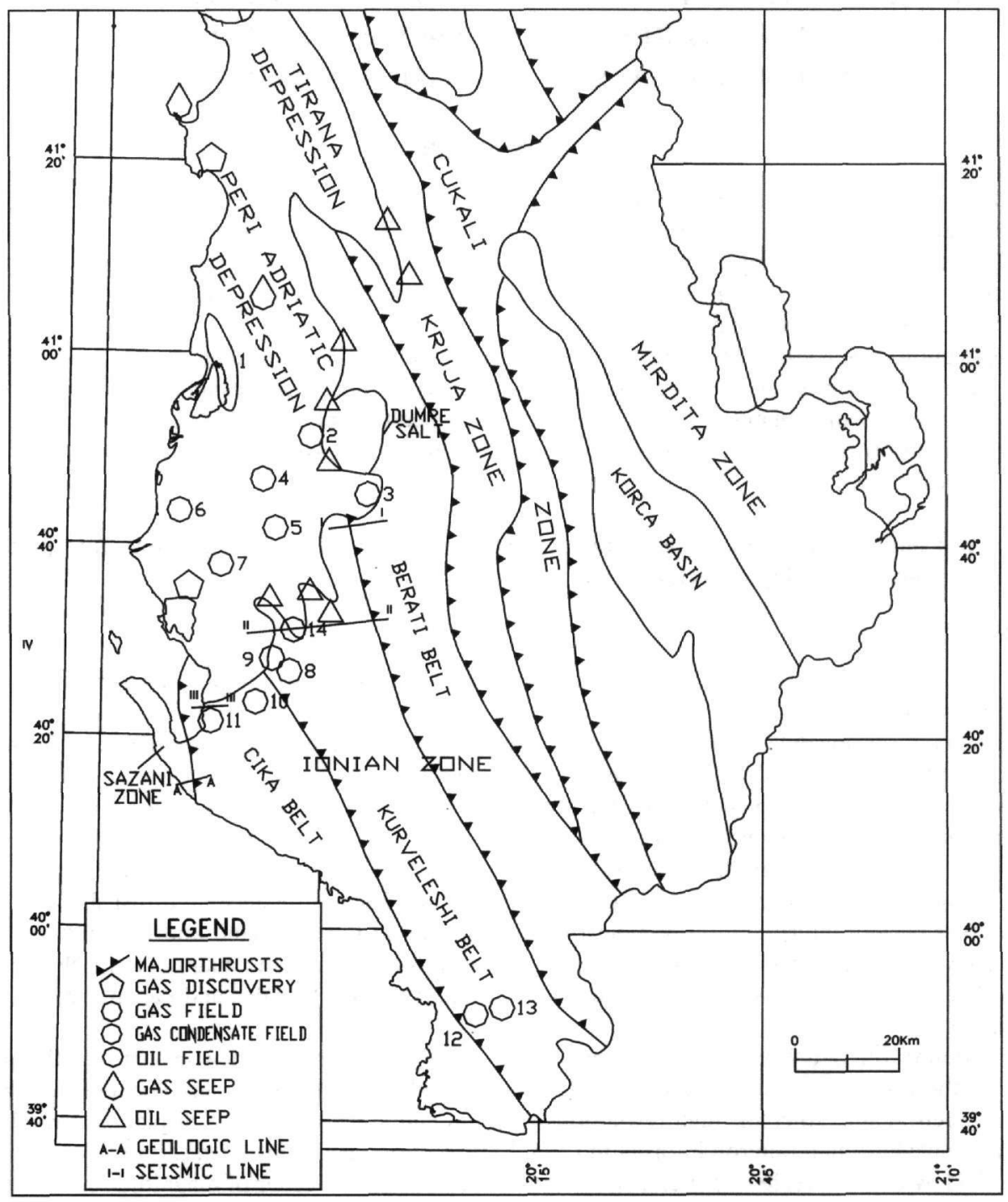

The seismic work acquisition on this belt is performed in different times and by different techniques. The seismic situation in the time sections is very complicated and for the top of limestone, only some separated reflections in certain lines are recorded. Seismic work in this belt has been of lower effectiveness (seismic line II Fig. 2) especially in its central and western parts, probably because limestones in this zone are deep and faulted (ref. 3).

This conclusion is well supported by the different wells drilled in Sqepur-Bistrovica area. In the eastern part of the belt, the Kucova and Qereshniku structures are clearly depicted by the seismic line. We can see clearly in Fig. 2 the Kucova structure and the eastern flank of Qereshniku. As we mentioned, the western part is chaotic.

In conclusion, according to the seismic work, limestones in the central part are markedly broken. 


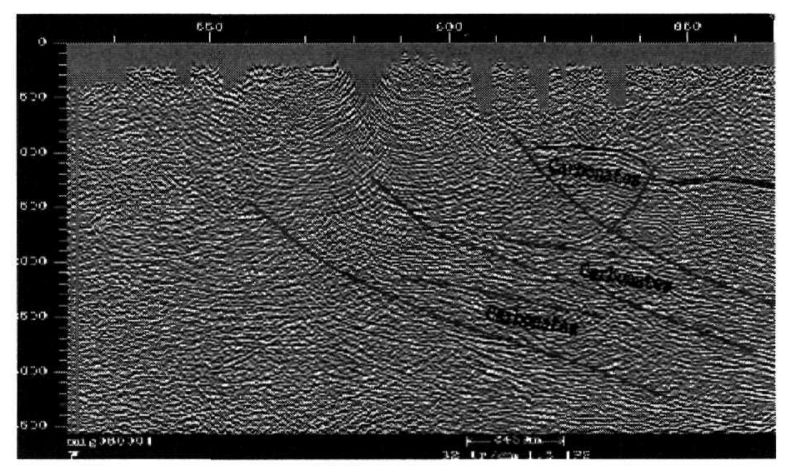

Fig. 2. Seismic line I-I across Berati belt

\section{B. Kurveleshi anticline belt}

All our conclusions refer mainly to carbonate formation, because those for the flysch, based on numerous facts,produced wrong conclusions(ref. 2).

In Fig. 3, seismic line II-II is shown which crosses the Ionian zone and from west to east we can see clearly the limestone thrusts and prospective structures for exploration.

The Ionian zone is very complicated by some tectonic faults. In the central part we can see the duplex tectonic style. Anticline belts form east to west can be interpreted.

The Kurveleshi belt is constructed by structures of various forms and dimensions associated with developed tectonics up to thrusting of 5-10 km horizontal displacement.

In Fig. 4, we can see the geological model derived from seismic lines across the Ionian zone, in the west of its structures as well as in eastern flanks associated with diapiric eruptions.

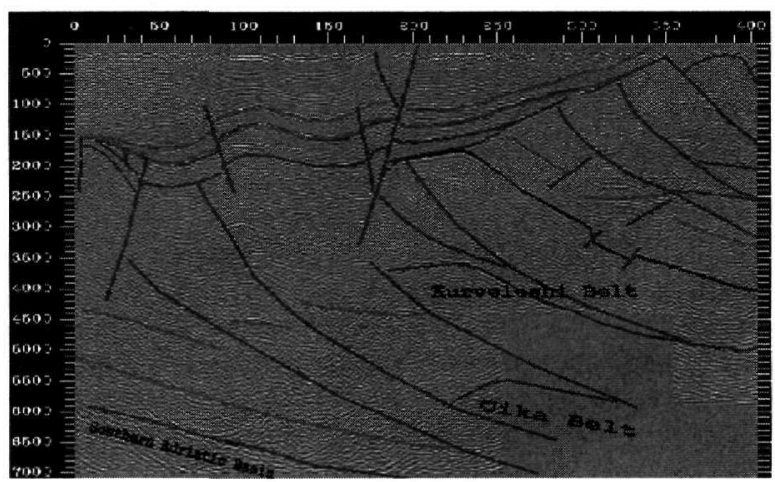

Fig. 3. Seismic line II-II across the Ionian zone

\section{Cika anticline belt}

Cika anticline belt is constructed mainly by prolonged structures in considerable dimensions associated with evaporate outcrops as in Xara, Fterra, Cika etc. Seismic works in this belt, date back to the start of exploration in Albania and still continue today. Earlier techniques for field acquisation have been those of one fold coverage, which continuously are improved, switching in the last years to multiple fold coverage.

The seismic exploration has been effective. A monocline flank in Vlora, seismic line III-III Fig.5, is clearly recorded.

In conclusion for the Ionian zone, the seismic contribution is effective in distinguishing the covered target.

By using seismic data, the structural maps are prepared, which gave useful contribution to the discovery of oil and gas fields and the orientation of exploration. Besides, with the structural interpretation by seismic data today, are able to resolve some specific duties. 


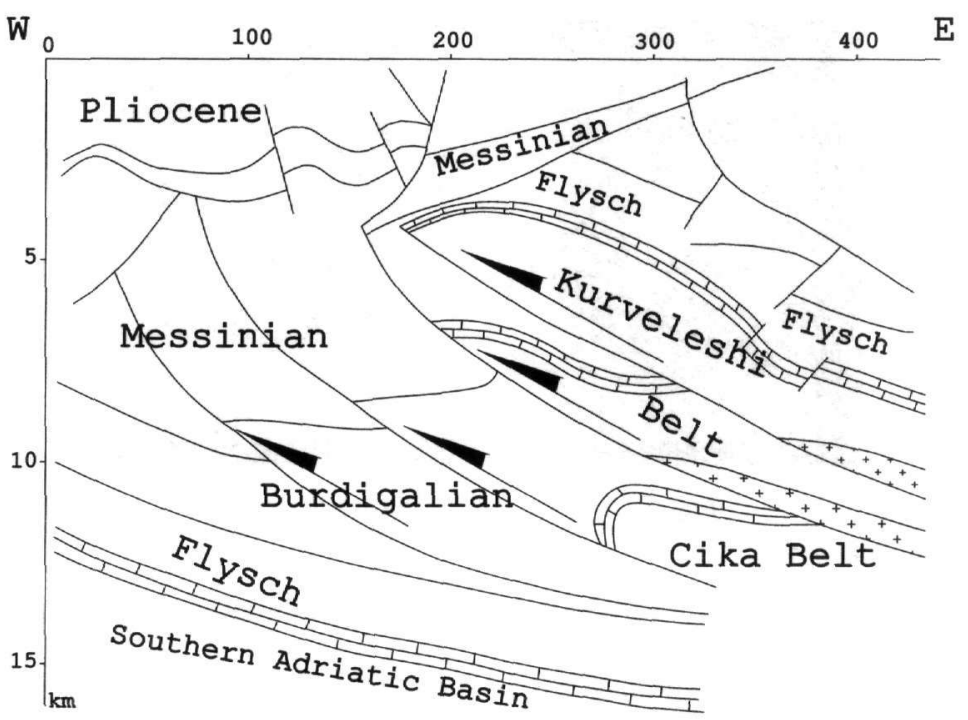

Fig. 4. Geological model of above seismic line

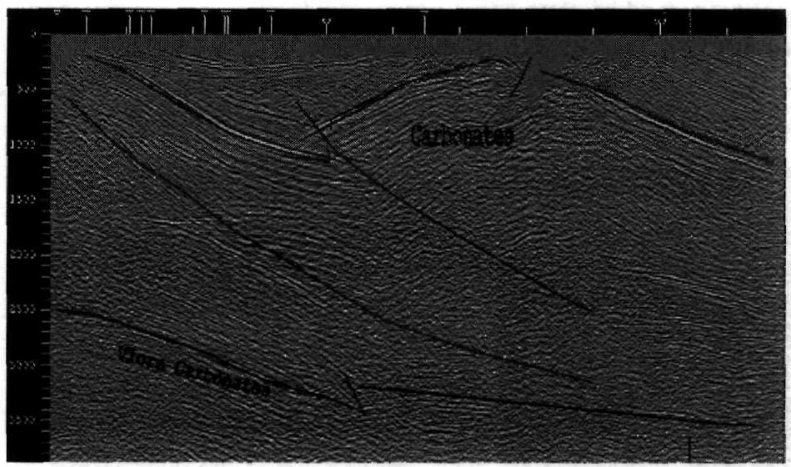

Fig. 5. Seismic line III-III across Cika belt

\section{RELATION BETWEEN TECTONIC ZONES AND THRUST BELTS}

The Kruja Zone thrusts over the Ionian zone. The belts in the Ionian zone are thrust to one other; every belt is one thrust sheet. The Berati belt, which is the eastern part, represents an out-of-sequence sheet(ref. 4).

The relation between Ionian and Sazani zones differs in various areas. In the south of the Ionian zone (Llogara area) eastern flank of the Sazani is tectonized creating uplift blocks, which collide with the Ionian zone, where it would be deep and underlying. Under the structural uplift of Cika belt the platform slope must continue with its respective change towards the basin.

Further in Sazani-Vlora parallel we can see the plunge of the platform slope, Fig.6

The space of platform slope is already extended and relatively little tectonized to pass into the most northern sector of Fieri parallel, which is actually a gentle, wide and deep slope, Fig 3., 4.

Considering the above, the complication is very high towards Southern External Albanides, it causes the Sazani zone to present an interesting settling over thrusting to Ionian zone, where as it is shown in the northern part, the Sazani zone underlies the Ionian zone.

From the viewpoint of its development history, this sector belongs to the platform slope due to very active tectonics. 


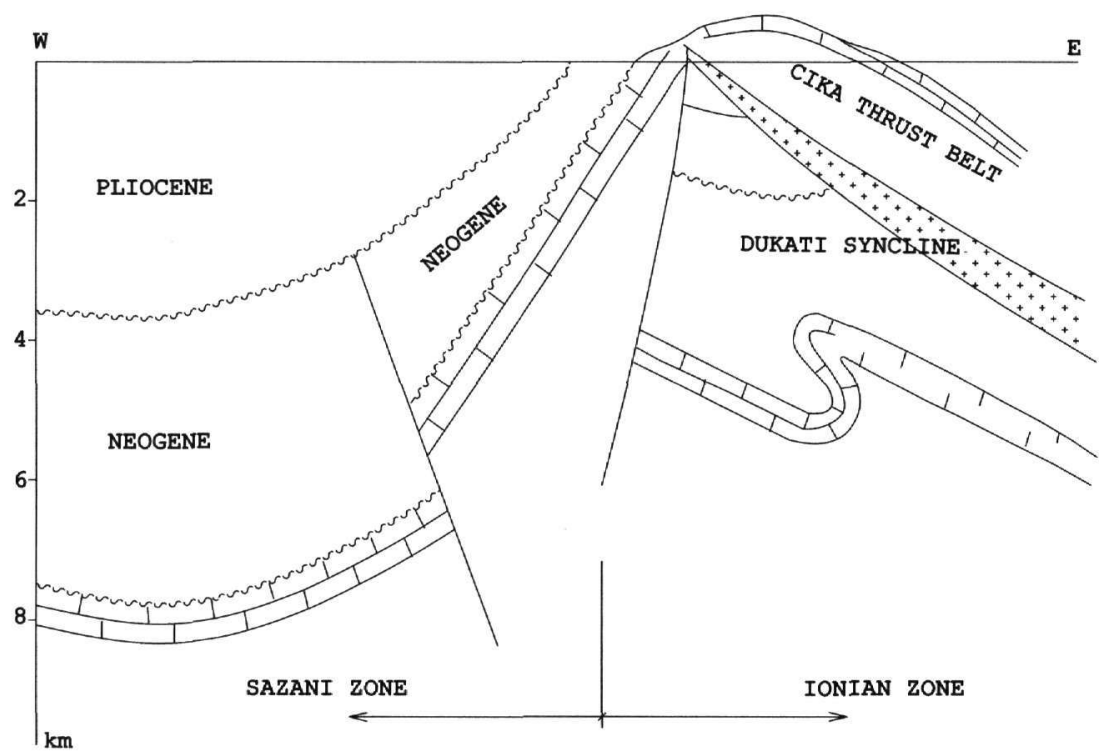

Fig. 6. Schematic Geological Cross Line (Llogara Area)

\section{CONCLUSIONS}

In conclusion for the Ionian zone, the seismic exploration is effective in distinguishing the covered target Application of the SeisWork2D as a powerful interpretative tool gives us new insight into the subsurface. The Ionian zone is characterized by an intensive thrusting and diapers eruptions. The belts in the Ionian zone are thrust over one other; every belt is one thrust sheet.

The Berati belt, which is the eastern part, represents an out-of-sequence sheet.

The Kurveleshi belt which is the main productive one is constructed by structures of various forms and dimensions associated with developed tectonics up to thrusting of 5-10 km horizontal displacement.

\section{REFERENCES}

A. FRASHERI, V. BARE, S. BALTADORI, V. VEIZAJ, 1995. The contribution of geophysical studies for Oil and Gas exploration on intentions for the future Symposium in Tirana, Albania

I. FILI, V. BARE, 1994. The relations between orogene and foreland in the South Eastern part of Albania. Abstract. $7^{\text {th }}$ Congress of Geological Society of Greece, Thessaloniki.

V. BARE, V. NGRESI, 1994. Seismic contribution in the study of geological structures of the southwest Albania. Abstract. Geological Symposium in Black Sea Varna, Bulgaria.

V. BARE, J. SKRAMI, 1995. Features of external Albanides structure based on the seismic data. Special publication of the Geological Society of Greece XV Congress of the Carpatho-Balcan Geological Association Athens, Greece. 